\title{
Configuration and Location of Small Urban Gardens Affect Colonization by Monarch Butterflies
}

\author{
Adam M. Baker and Daniel A. Potter* \\ Department of Entomology, University of Kentucky, Lexington, KY, United States
}

Ecological theory predicts that specialist insect herbivores are more likely to locate and colonize host plants growing in relatively sparse or pure stands compared to host plants growing amongst diverse non-host vegetation. We tested the hypothesis that increasing the apparency and accessibility of milkweed (Asclepias spp.) host plants in small polyculture gardens would boost their colonization by the monarch butterfly (Danaus plexippus), an iconic native species of conservation concern. We established replicated gardens containing the identical mix of milkweeds, flowering nectar sources, and non-host ornamental grasses but arranged in three different spatial configurations that were monitored for monarch colonization over two successive growing seasons. Monarch eggs and larvae were 2.5-4 times more abundant in gardens having milkweeds

OPEN ACCESS

Edited by:

J. Guy Castley,

Griffith University, Australia

Reviewed by:

Martha Weiss,

Georgetown University, United States

Douglas Landis,

Michigan State University,

United States

*Correspondence:

Daniel A. Potter

dapotter@uky.edu

Specialty section:

This article was submitted to

Conservation,

a section of the journal

Frontiers in Ecology and Evolution

Received: 06 September 2019

Accepted: 22 November 2019

Published: 05 December 2019

Citation:

Baker AM and Potter DA (2019)

Configuration and Location of Small

Urban Gardens Affect Colonization by

Monarch Butterflies.

Front. Ecol. Evol. 7:474.

doi: 10.3389/fevo.2019.00474 evenly spaced in a $1 \mathrm{~m}$ corridor around the perimeter, surrounding the nectar plants and grasses, than in gardens in which milkweeds were surrounded by or intermixed with the other plants. Predator populations were similar in all garden designs. In a corollary open-field experiment, female monarchs laid significantly more eggs on milkweed plants that were fully accessible than on milkweeds surrounded by non-host grasses of equal height. In addition, we monitored monarch usage of 22 citizen-planted gardens containing milkweed and nectar plants in relation to their botanical composition, layout, and surrounding hardscape. Multivariate analysis explained $71 \%$ of the variation, with significantly more eggs and larvae found in gardens having milkweeds spatially isolated as opposed to closely intermixed with non-host plants, and in gardens having $100 \mathrm{~m}$ north/south access unimpeded by structures. Numerous programs encourage citizens to establish gardens with milkweed and nectar plants to help offset habitat loss across the monarch's breeding range. Our findings suggest guidelines for garden design that can help make the urban sector's contributions to monarch habitat restoration more rewarding for participants, and of greater potential value to monarch recovery.

Keywords: Danaus plexippus, reconciliation ecology, conservation biology, citizen science, Asclepias, garden, urban

\section{INTRODUCTION}

Reconciliation ecology, "the science of inventing, establishing, and maintaining new habitats to conserve species diversity in places where people live, work, and play" (Rosenzweig, 2003a) aims to modify human-dominated landscapes to support native biota without compromising societal utilization (Rosenzweig, 2003a,b; Francis and Lorimer, 2011). As natural habitats increasingly are 
cleared, fragmented and degraded by anthropogenic activities, properly designed urban green spaces, including pollinator gardens, can be refuges for native biodiversity, particularly of invertebrates, birds, and other animals able to adapt to human proximity (Goddard et al., 2010; Baldock et al., 2015; Hall, 2016; Aronson et al., 2017). Reconciliation ecology also provides opportunities for urban citizens to connect with nature, helping to foster a wider interest in conservation issues (Goddard et al., 2010; Lepczyk et al., 2017). Among insects of conservation concern, none exceeds the power of the monarch butterfly (Danaus plexippus L.) to inspire public engagement in reconciliation ecology (Gustafsson et al., 2015).

Instantly recognizable by gardeners and nature lovers, the iconic monarch is renowned for its annual migration in which butterflies from discrete overwintering areas in the highlands of central Mexico recolonize breeding grounds across the United States and southern Canada east of the Rocky Mountains over several generations, followed by a single autumn migration back to Mexico (Reppert and de Roode, 2018). The eastern migratory monarch population has declined $>80 \%$ in the past 25 years (Brower et al., 2011; Vidal and Rendón-Salinas, 2014), fueling concern that it may face extirpation unless habitat conservation and restoration efforts are enacted on a continental scale. The monarch population in western North America is also in sharp decline (Schultz et al., 2017). The US Fish and Wildlife Service (USFWS) is currently assessing the monarch's status in response to a petition to list the species under the Endangered Species Act, while working with a broad range of partners as part of an international initiative to conserve the butterfly across its range ${ }^{1,2}$.

Given that monarch larvae feed exclusively on milkweed (family Apocynaceae, subfamily Asclepiadoideae), and that adults migrate to locate host plants across diverse landscapes, two primary concerns facing monarch populations are shortages of milkweed, and floral nectar to fuel migration (Pleasants and Oberhauser, 2013; Oberhauser et al., 2017; Malcolm, 2018; Saunders et al., 2019). Conserving and restoring monarch habitat, especially planting of milkweeds and nectar resources on public and private lands, has emerged as the central conservation strategy to meet monarch population goals set by the USFWS and adopted by Mexico, Canada, and the United States ${ }^{1,2}$. Most research on monarch habitat restoration to date has focused on "non-use" land, e.g., publicly owned grasslands, road right-ofways, Conservation Reserve Program land, edges of fields and pastures, and other marginal habitat (e.g., Kasten et al., 2016; Oberhauser et al., 2017; Pitman et al., 2018). However, restoring enough milkweed to ensure a stable monarch population will require an "all hands on deck" strategy involving participation from all land use sectors including urban and suburban areas (Thogmartin et al., 2017; Johnston et al., 2019). In cities and towns, initiatives such as the Million Pollinator Garden

\footnotetext{
${ }^{1}$ https://www.fws.gov/savethemonarch/

${ }^{2}$ https://monarchjointventure.org/images/uploads/documents/ 5431_Monarch_en.pdf
}

Challenge $^{3}$, the Monarch Waystation Program ${ }^{4}$, National Wildlife Federation's Butterfly Heroes program ${ }^{5}$, and Mayor's Monarch Pledge ${ }^{6}$ are underway, with myriad gardens being planted in backyards, schoolyards, parks, and other public and private places. As of 2019, >25,000 Monarch Waystation habitats (managed gardens containing milkweeds and nectar plants) had been registered with MonarchWatch ${ }^{4}$ and the National Pollinator Garden Network ${ }^{3}$ had surpassed its goal of registering $>1,000,000$ pollinator gardens, many likely containing milkweed.

Guidelines for setting up a certified Monarch Waystation ${ }^{4}$ recommend that such gardens should have "at least 10 milkweed plants, made up of two or more species," "should contain several annual, biennial, or perennial plants that provide nectar for butterflies," and that "the plants should be relatively close together" because "all monarch life stages need shelter from predators and the elements." Monarchs find and colonize milkweed in urban gardens (Cutting and Tallamy, 2015; Baker and Potter, 2018; Geest et al., 2019), but little is known about how to configure such gardens to maximize their conservation value.

Ecological theory (e.g., Root, 1973; Andow, 1991) suggests ways to increase monarch use of milkweed gardens. Susceptibility of plants to attack by insect herbivores may be strongly influenced by the structural and taxonomic complexity of surrounding vegetation (Tahvanainen and Root, 1972; Root, 1973; Rausher, 1981). Dietary specialists, in particular, tend to have difficulty locating host plants growing amongst non-host vegetation, and are less likely to remain on hosts grown in polyculture (Root, 1973; Finch and Collier, 2000). Mechanisms proposed for such "associational resistance" (Tahvanainen and Root, 1972) include visual or olfactory masking, repellent odors, physical obstruction or shading, or inappropriate landings on non-hosts triggering herbivores' premature dispersal (Tahvanainen and Root, 1972; Root, 1973; Risch, 1981; Finch and Collier, 2000). Neighboring plants may also provide harborage and food resources for natural enemies (Root, 1973; Risch, 1981). The aim in polyculture agriculture is to discourage host-finding and colonization by specialist herbivores. The goal for monarch conservation gardens is just the opposite.

We hypothesized that the spatial configuration of host and non-host plants within small gardens, particularly the milkweeds' visual apparency and butterflies' access to them, as well as location of gardens relative to surrounding hardscape, would strongly affect their colonization and use by monarchs. Here, we tested those hypotheses by monitoring (1) monarch use of 22 preexisting citizen-planted Monarch Waystations in relation to those gardens' botanical composition, configuration, and surrounding hardscape, (2) colonization of experimental gardens containing an identical mix of milkweeds, nectar sources, and non-host grasses, but planted in different spatial layouts, and (3) oviposition on isolated milkweeds and milkweeds that were visually obstructed by non-host vegetation.

\footnotetext{
${ }^{3}$ http://millionpollinatorgardens.org/

${ }^{4}$ https://www.monarchwatch.org/

${ }^{5}$ https://www.nwf.org/Butterfly-Heroes.aspx

${ }^{6}$ https://www.nwf.org/mayorsmonarchpledge
} 


\section{MATERIALS AND METHODS}

\section{Monarch Use of Preexisting Waystations}

Twenty-two preexisting registered Monarch Waystation gardens were identified via the Monarch Waystation Registry ${ }^{4}$ or through the Wild Ones ${ }^{7}$ Lexington, Kentucky Chapter, and monitored with permission from landowners or other authorized persons. The Waystations were in residential, commercial, and institutional landscapes, road medians, parks, and nature preserves encompassing a range of anthropogenic settings in and near the cities of Lexington, Richmond, and Berea, in central Kentucky. All of the gardens were mulched, and contained at least three Asclepias species, swamp (A. incarnata), common ( $A$. syriaca), and butterfly (A. tuberosa) milkweeds, as well as a variety of annual and perennial flowering plants. Each Waystation was visited twice per month from 5 July to 20 September 2016. Each time, we inspected all milkweeds for monarch eggs and larvae, which were counted and left in place. Monarch eggs and larvae were observed in 20 of the 22 Monarch Waystations.

The Waystations were further characterized by features of the gardens and their surrounding landscape. Garden configuration was classified into two types: "structured" or "non-structured." In structured gardens $(N=9)$, the milkweeds had been planted in a relatively uniform array, set off by mulch, and separated from neighboring plants by $0.5 \mathrm{~m}$ or more. Non-structured gardens $(N$ $=13$ ) were also mulched, but had the milkweeds haphazardly intermixed with nectar and non-host plants in no particular arrangement, their foliage often touching or partially shaded by nearby plants. Other garden variables included total area, number of ramets of each milkweed species (counted during bloom when the plants were done producing new ramets for the year), and number of nectar plants.

We used satellite images and the Measure Tool feature of Google Earth Pro geospatial software (Microsoft, Palo Alto CA) to quantify the area of buildings and other hardscape within a $100 \mathrm{~m}$ radius centered each garden, the ratio of impervious to pervious surfaces, and distance of the garden to nearby structures. Linear transects were drawn from the garden through corners of all buildings to the edge of the circle. We summed the angles defined by those transects, divided by $360^{\circ}$, and subtracted from 1 to calculate a " $360^{\circ}$ accessibility index"; i.e., the proportion of access not blocked by buildings if an incoming butterfly approached the garden from $100 \mathrm{~m}$ away. Because monarchs fly predominantly northward during their spring migration and south toward their overwintering grounds during fall migration, we hypothesized that unimpeded lines of sight from those directions to resources may be important. Therefore, we determined straight line north/south access by scoring whether or not flight of a butterfly approaching the garden from due north or due south would be blocked by structures.

\section{Monarch Use of Experimental Gardens of Differing Configurations}

Fifteen gardens $(5.5 \times 5.5 \mathrm{~m})$ were established in spring 2017 in open, non-shaded grassland at the University of Kentucky

${ }^{7}$ https://lexington.wildones.org/
Spindletop Research Farm $\left(38^{\circ} 07^{\prime} 35.9^{\prime \prime} \mathrm{N} 84^{\circ} 29^{\prime} 58.1^{\prime \prime} \mathrm{W}\right)$ in north Lexington, Kentucky. To establish the gardens, plots were sprayed with glyphosate (Roundup ProMax, Monsanto, St. Louis, $\mathrm{MO}$ ) in April to kill existing vegetation, tilled, and covered with weed barrier cloth. Each garden contained the same mix of swamp milkweed, nectar plants, and ornamental grasses in one of three different spatial configurations, representing treatments: (1) milkweeds evenly spaced in a $1 \mathrm{~m}$ wide corridor around the perimeter with nectar plants and grasses in the interior (Figure 1A); (2) nectar plants and grasses in a $1 \mathrm{~m}$ corridor around the perimeter with milkweed in the interior (Figure 1B); or (3) random arrangement of all plants without formal garden structure (Figure 1C), hereafter referred to as gardens with "perimeter milkweeds," "interior milkweeds," and "mixed," respectively. Gardens were placed on $300 \mathrm{~m}$ transects (100 $\mathrm{m}$ spacing between treatments) oriented on an east-west axis within each replicate to minimize bias in their likelihood of being encountered during flight of north or south bound monarch butterflies. Each of the five replicates was separated by at least $300 \mathrm{~m}$.

We used swamp milkweed, A. incarnata, because it grows to a consistent height of about $1 \mathrm{~m}$ and does not spread via rhizomes (Baker and Potter, 2018). Two-year old potted plants $(30 \mathrm{~cm}$ tall) were transplanted (12 per garden) in early May 2017. To increase the structural and taxonomic complexity of the vegetation surrounding the milkweeds, each garden also contained flowering annuals differing in height and form, including Mexican sunflower, Tithonia rotundifolia (12 per garden) and common zinnia, Zinnia elegans "Canary Bird" (12 per garden), which are attractive nectar sources for adult monarchs, and ornamental feather reed grass, Calamagrostis $\times$ acutiflora (four per garden). Mexican sunflower grows to $1.2-$ $1.5 \mathrm{~m}$ height and $0.6-0.9 \mathrm{~m}$ spread; Z. elegans to $0.6-0.9 \mathrm{~m}$ height and $0.2-0.3 \mathrm{~m}$ spread, and Calamagrostis reaches $0.9-1.5 \mathrm{~m}$ height and $0.45-0.76 \mathrm{~m} \mathrm{spread}^{8}$. Nectar plants were greenhousegrown from seeds (Applewood Seed, Arvada, CO), whereas the ornamental grasses were purchased in 11.5 liter pots (Baeten's Nursery, Union, KY).

For gardens with perimeter milkweeds, the $12 \mathrm{~A}$. incarnata were planted with even spacing in the $1 \mathrm{~m}$ border, $1.5 \mathrm{~m}$ apart, and the Tithonia, Zinnia, and Calamagrostis were evenly spaced within the inner block with one grass transplanted at each of the four cardinal directions (Figure 1A). For gardens with interior milkweeds (Figure 1B), the $12 \mathrm{~A}$. incarnata were spaced $1.1 \mathrm{~m}$ apart in the inner block, with the Tithonia and nectar plants alternated evenly around the perimeter in the $1 \mathrm{~m}$ border, and for mixed gardens (Figure 1C), all plants were assigned to random distribution over the whole plot. Each garden received a $5 \mathrm{~cm}$ deep layer of dark-brown mixed hardwood mulch over the entire plot and surrounding all plants. The gardens were watered to maintain plant vigor for a month after planting, but received only natural rainfall for the duration of the study. They were handweeded, and re-mulched at the start of the second (2018) growing season, at which time a few of the less-vigorous milkweeds were replaced with similar-sized healthy 2 -year-old plants. The

${ }^{8} \mathrm{http} / / /$ www.missouribotanicalgarden.org/plantfinder/plantfindersearch.aspx 

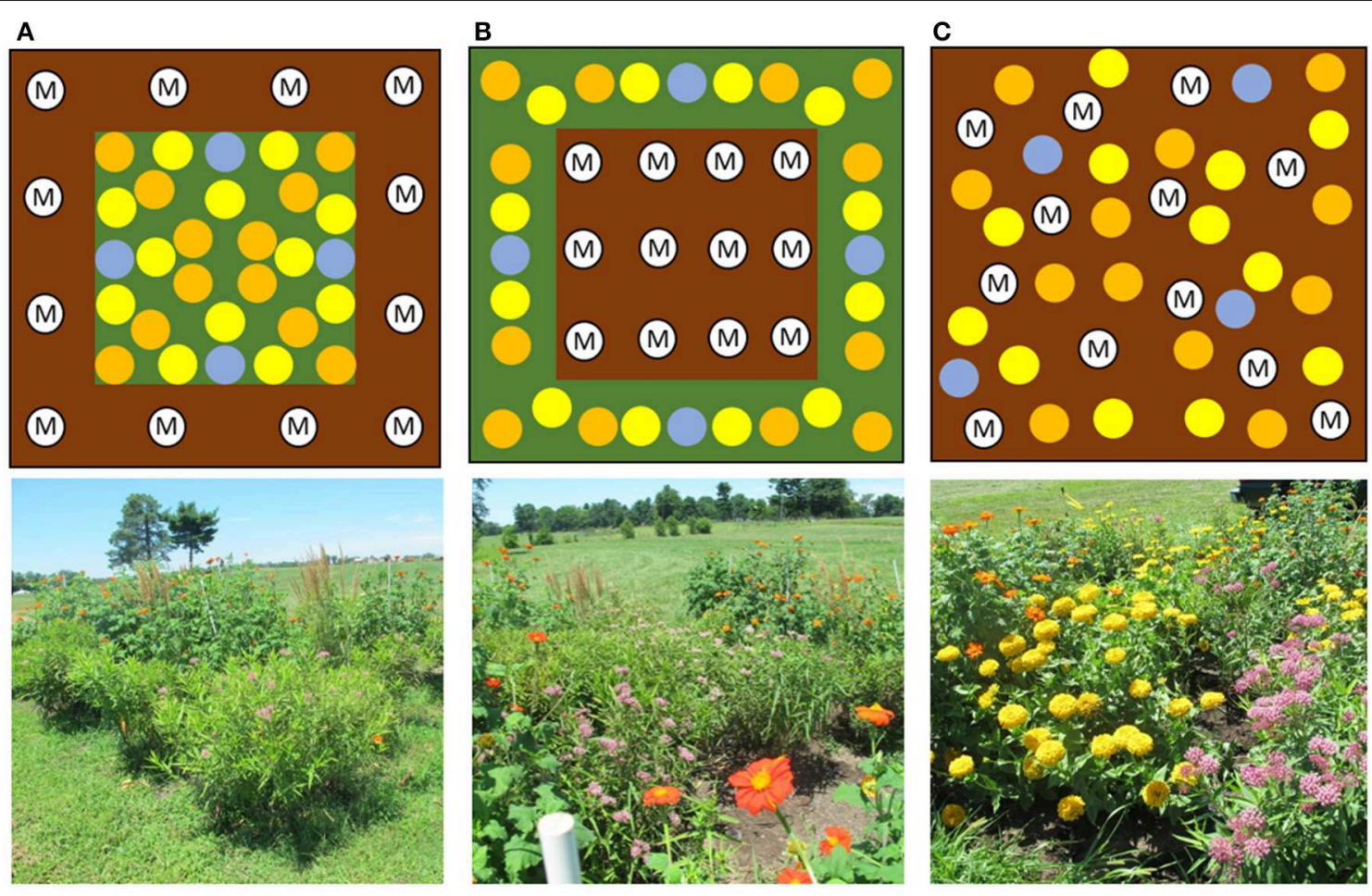

\section{(M) Asclepias incarnata \\ Tithonia rotundifolia \\ Zinnia elegans \\ Calamagrostis $x$ acutiflora}

FIGURE 1 | Layout of the three garden designs tested. Top row, left to right: (A) milkweed plants on the perimeter of the garden (M), spacing with mulch (brown), nectar/camouflage plants on interior of garden [Tithonia rotundifolia (orange), Zinnia elegans (yellow), and Calamagrostis $x$ acutiflora (blue)]; (B) milkweed on the interior of the garden and placement of the nectar/camouflage plants on exterior of garden; (C) no formal design to simulate a naturalized or mixed garden. Milkweed and nectar/camouflage plants were placed randomly throughout each quadrant in the gardens. Bottom row, left to right: gardens of the aforementioned designs, respectively, as they appeared in 2018.

grass (mostly tall fescue, Festuca arundinacea) surrounding each garden was mowed weekly to $10 \mathrm{~cm}$ height.

\section{Assessing Monarch Colonization and Use of Gardens Gardens were inspected for all monarch life stages during the 1st and 3rd week of each month from June to September 2017, and during the 2nd and 4th week of each month beginning 9 April until 23 July 2018, when a severe storm uprooted the taller, mostly Tithonia nectar plants, reducing integrity of the treatments. At each visit we carefully inspected above-ground portions of each milkweed by examining the stems, and the top and bottom of each leaf for monarch eggs, larvae, and pupae which were counted and left in place.}

\section{Natural Enemy Abundance in Gardens}

Two methods were used to assess if garden design influenced abundance of generalist invertebrate predators in the gardens. First, all above-ground portions of the 12 milkweeds in each garden were inspected every 2 weeks from June to September 2017, and April to July 2018 on alternate weeks from when monarch life stages were counted. We recorded numbers of adults and immatures belonging to predominantly predatory taxa on each plant, spot-identifying to order and family and leaving them in place. Predatory wasps seen nectaring on the milkweed umbels were not counted.

Abundance of ground-dwelling predators that monarch larvae might encounter while moving between plants or to pupation sites was assessed using pitfall traps deployed for $48 \mathrm{~h}$ from July $19-21$ and July $26-28,2018$, during peak monarch activity. Traps consisted of 0.47 liter plastic cups, with $2 \mathrm{~cm}$ of ethylene glycol as a killing agent, set into the ground with the brim $2 \mathrm{~cm}$ below the surface. There were four traps per garden spaced at least $2 \mathrm{~m}$ apart, but within $1 \mathrm{~m}$ of the milkweed. Trapped invertebrates were stored in 70\% ethanol, and sorted and identified to order and family.

\section{Effect of Surrounding Vegetation on Susceptibility of Milkweeds to Oviposition}

A supplemental experiment investigated how presence or absence of surrounding non-host vegetation affects a milkweed plant's susceptibility to monarch oviposition. The trial ran from 6 to 21 August 2018 in an open grassy area of the University of Kentucky State Botanical Garden and Arboretum $\left(38^{\circ} 00^{\prime} 57.5^{\prime \prime} \mathrm{N}\right.$ $84^{\circ} 30^{\prime} 15.7^{\prime \prime} \mathrm{W}$ ), Lexington, KY. Six pairs (replicates) of $A$. 
incarnata (about $90 \mathrm{~cm}$ tall) in 4 liter pots were sunk into the soil so that the pot rims were even with the ground surface. Plants within replicates were spaced $9 \mathrm{~m}$ apart along an east-west transect, with replicates separated by at least $11 \mathrm{~m}$. One randomly-chosen milkweed of each pair was surrounded by three clumps of ornamental grasses, Panicum virgatum "Shenandoah," in 11 liter pots that were placed in a triangular array at $0.6 \mathrm{~m}$ distance. The uppermost foliage of the grasses and milkweeds was at similar height, with their foliage separated by about $0.5 \mathrm{~m}$, but the grasses close enough that they might form a visual screen to monarchs flying over the landscape in search of milkweed for oviposition. The milkweeds were inspected daily for monarch eggs, and at each visit, such eggs were removed.

\section{Statistical Analysis}

Data relating the characteristics of the preexisting Monarch Waystations and total number of monarch eggs and larvae found in those gardens were analyzed by multivariate analysis of variance (ANOVA) using the Statistical Analysis System general linear models procedure (SAS, Version 9.4; SAS Institute, Cary, NY, USA) to test for associations between monarch abundance and garden characteristics including area, milkweed density, nectar plant density, and whether or not the garden configuration was structured or non-structured, as well as surrounding landscape features within a $100 \mathrm{~m}$ radius of the garden including \% hardscape, number, and total area of buildings, distance to nearest building, $360^{\circ}$ accessibility index, and north/south accessibility. We used stepwise model selection to omit independent variables not producing a significant $F$ statistic and calculate adjusted $r^{2}$ values for the full and reduced models.

Counts of monarch life stages on the milkweeds were summed across sample dates, within year, and those totals were compared between garden layouts by two-way (ANOVA) for a randomized complete block design using Statistix 10 (Analytical Software, Boca Raton, FL). Direct counts of predatory invertebrates on the milkweeds, and numbers captured in the pitfall traps, were similarly analyzed for each data set, as were numbers of monarch eggs deposited on milkweeds that were or were not surrounded by ornamental grasses. Log or square root transformations were used if needed to meet normality and homogeneity of variance assumptions. Data are reported as original means \pm standard error (SE).

\section{RESULTS}

\section{Monarch Use of Preexisting Waystations}

Multivariate analysis of variance for predictors of monarch egg and larval abundance in the 22 citizen-planted Monarch Waystations explained 63 and $71 \%$ of the variation with complete and reduced models, respectively (Table 1). Stepwise model selection identified three factors: garden configuration, north/south accessibility, and proximity to nearest building as significant sources of variation. Total numbers of monarch
TABLE 1 | Summary of analysis of variance for the effects of garden characteristics and landscape features on the number of monarch eggs and larvae observed in gardens.

\begin{tabular}{|c|c|c|c|c|}
\hline Garden characteristics ${ }^{a}$ & df & $\boldsymbol{F}$ & $\operatorname{Pr}>F$ (full) & $\operatorname{Pr}>F$ (reduced) \\
\hline Garden area & 1 & 0.02 & 0.89 & - \\
\hline Milkweed ramet density & 1 & 1.35 & 0.27 & - \\
\hline Nectar plant density & 1 & 0.39 & 0.55 & - \\
\hline Plant Separation & 1 & 16.49 & $<0.01$ & $<0.01^{*}$ \\
\hline \multicolumn{5}{|l|}{ Landscape features $^{b}$} \\
\hline Accessibility index $360^{\circ}$ & 1 & 0.35 & 0.57 & - \\
\hline Line of sight North/South & 1 & 5.42 & 0.04 & $<0.01^{\star}$ \\
\hline Area occupied by structures & 1 & 1.37 & 0.27 & - \\
\hline \% Hardscape & 1 & 1.75 & 0.21 & - \\
\hline Proximity to nearest structure & 1 & 5.95 & 0.33 & $0.01^{*}$ \\
\hline Number of structures & 1 & 0.39 & 0.54 & - \\
\hline
\end{tabular}

Adjusted $r^{2}$ full model; 0.63, reduced model; 0.71 .

${ }^{a}$ Garden area $\left(\mathrm{m}^{2}\right)$, milkweed ramet density, nectar plant density, plant spacing (use of mulch to achieve plant separation) in garden.

${ }^{b}$ All measurements based on $100 \mathrm{~m}$ radius buffer zone around center of gardens. Accessibility index (degrees visually obstructed out of $360^{\circ}$ ), line of sight north/south (visual obstruction north/south), area occupied by structures (\% of buffer zone), \% hardscape (includes buildings and any impenetrable surfaces), proximity to nearest structure, number of structures.

Significant variables that were retained from the full model during stepwise model selection indicated by $\left({ }^{*}\right)$.

eggs and larvae observed in twice-monthly visits to each garden were about five-fold higher in structured gardens with spacing between milkweeds and non-host plants than in non-structured gardens where those plants were closely intermixed (Figure 2A), and similarly higher in gardens with unobstructed north-south access compared to ones where such access was obstructed by buildings (Figure 2B). There was also a positive relationship between monarch abundance and proximity to the nearest structure. Other features of the gardens themselves (area, density of milkweeds, or nectar plants) or of the surrounding landscape with a $100 \mathrm{~m}$ radius did not explain a significant amount of variance in use by monarchs (Table 1). The gardens varied with respect to percentage of surrounding area occupied by hardscape (5-78\%) and degrees of $360^{\circ}$ access impeded by buildings or other structures $\left(0-360^{\circ}\right)$.

All 22 gardens contained $A$. incarnata, $A$. syriaca, and $A$. tuberosa which were nearly equally represented (Figure $2 \mathrm{C}$ ). Two gardens also contained one or two plants of $A$. verticillata (whorled milkweed), but no other milkweed species were represented. Total milkweed ramets per garden averaged $54 \pm 8.7$ (range 10-198). Total numbers of eggs and larvae found in the six, twice-monthly inspections averaged $13.3 \pm 3.9$ per garden, with high variability (range 0-61) between garden sites. Across all gardens, we found a total of 137, 134, and 11 monarch eggs and larvae on 380,437 , and 312 ramets of A. incarnata, A. syriaca, and $A$. tuberosa, respectively, with proportionately more on $A$. incarnata and $A$. syriaca than on $A$. tuberosa $\left(\chi^{2}=109.0, P\right.$ $<0.001$; Figure 2D). Monarch abundance (total for all garden counts) built up over the growing season, peaking in September. 

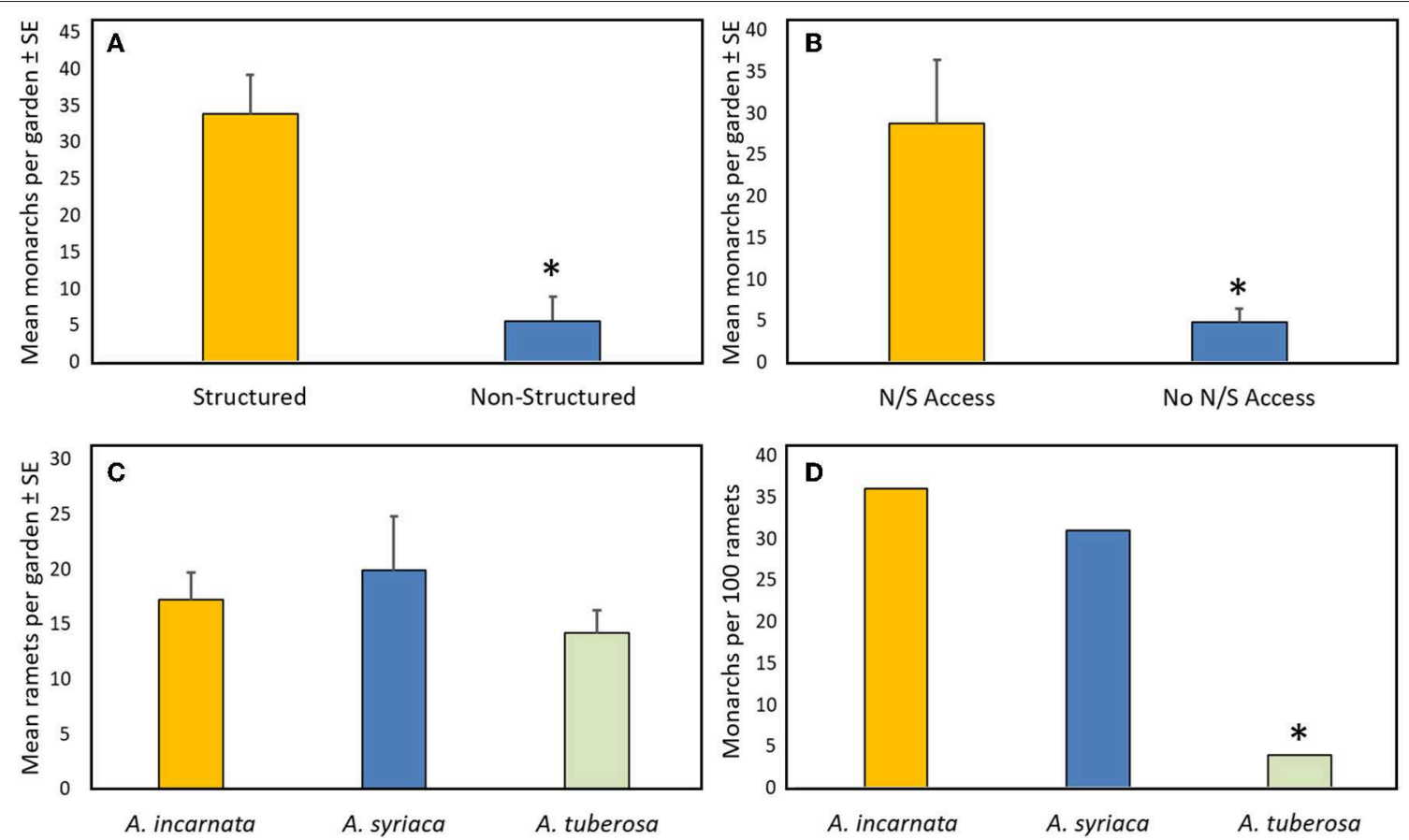

FIGURE 2 | Summary data from season-long survey of citizen-planted Monarch Waystations ( $N=22)$ : (A) Mean total monarchs (eggs and larvae) in structured gardens (milkweeds in uniform array, separated from other plants by $\geq 0.5 \mathrm{~m}$ ) or non-structured gardens (milkweeds closely intermixed with non-host plants); (B) Mean total monarchs (eggs and larvae) in gardens with or without unimpeded north-south access to $100 \mathrm{~m}$ : (C) Mean total ramets per garden of the three predominant milkweed species; (D) Mean total monarch eggs and larvae per 100 ramets of each milkweed species. Asterisk denotes significant difference. See text and Table 1 for statistical comparisons.

\section{Monarch Use of Experimental Gardens of Differing Configurations}

In both 2017 and 2018 monarch eggs and larvae were 2.5-4 times more abundant in gardens in which the milkweeds were planted around the perimeter, surrounding the nectar plants and grasses, than when the layout was reversed, with milkweeds in the garden interior, or when the milkweeds were randomly intermixed with the other plants (Figure 3).

All three garden configurations harbored similar communities of predatory arthropods. Lady beetle adults and larvae (Coccinellidae), lacewings (Chrysopidae), and spiders (Araneae) were the most abundant predators observed on the milkweed plants (Figures 4A,B) with smaller numbers of ants, predatory Hemiptera (Pentatomidae, Reduviidae, and Nabidae) and others. Direct counts on the milkweeds did not differ among garden types for any predator group [Figures $\mathbf{4 A , B} ; F_{(2,8)} \leq$ 1.7 for all individual taxa; all $P \geq 0.24]$. Ground-dwelling predators captured in pitfall traps included ants, spiders, ground beetles (Carabidae), rove beetles (Staphylinidae), harvestmen (Opiliones), and other groups (Figure 4C). Garden design had no effect on activity-density of any of those groups $\left[F_{(2,8)} \leq 1.5\right.$ for all individual taxa; all $P \geq 0.27$.

\section{Effect of Surrounding Vegetation on Susceptibility of Milkweeds to Oviposition}

Female monarchs foraging in an open-field setting laid significantly more eggs on single milkweed plants that were accessible from top to bottom, without visual obstruction, compared to single plants surrounded by, but not touching, ornamental grasses of equal height (Figure 5). Milkweeds screened by the grasses received almost no eggs over the 2week trial.

\section{DISCUSSION}

Numerous programs ${ }^{1-7}$ encourage individual landowners, citizen scientists, and organizations in residential areas to establish gardens with milkweed and nectar plants to help offset habitat loss across the monarch's breeding range, and to increase connectivity among habitat patches in other land types. Optimizing the conservation value of such gardens is important because of the substantial effort and resources being directed toward them, and because restoring monarchs to a population goal specified in the North American Monarch Conservation Plan will likely require contributions from all land use sectors (Pleasants, 2017; Thogmartin et al., 2017). Indeed, geospatial extrapolations indicate that if all metropolitan areas across the US eastern range were engaged, they could provide nearly a third of the projected milkweed needed to sustain the eastern monarch population (Johnston et al., 2019).

To contribute to monarch conservation, gardens must first attract females to lay eggs. Monarchs find and oviposit on milkweeds in small urban gardens, often with higher egg-loading per plant than in natural habitats (Cutting and Tallamy, 2015; 


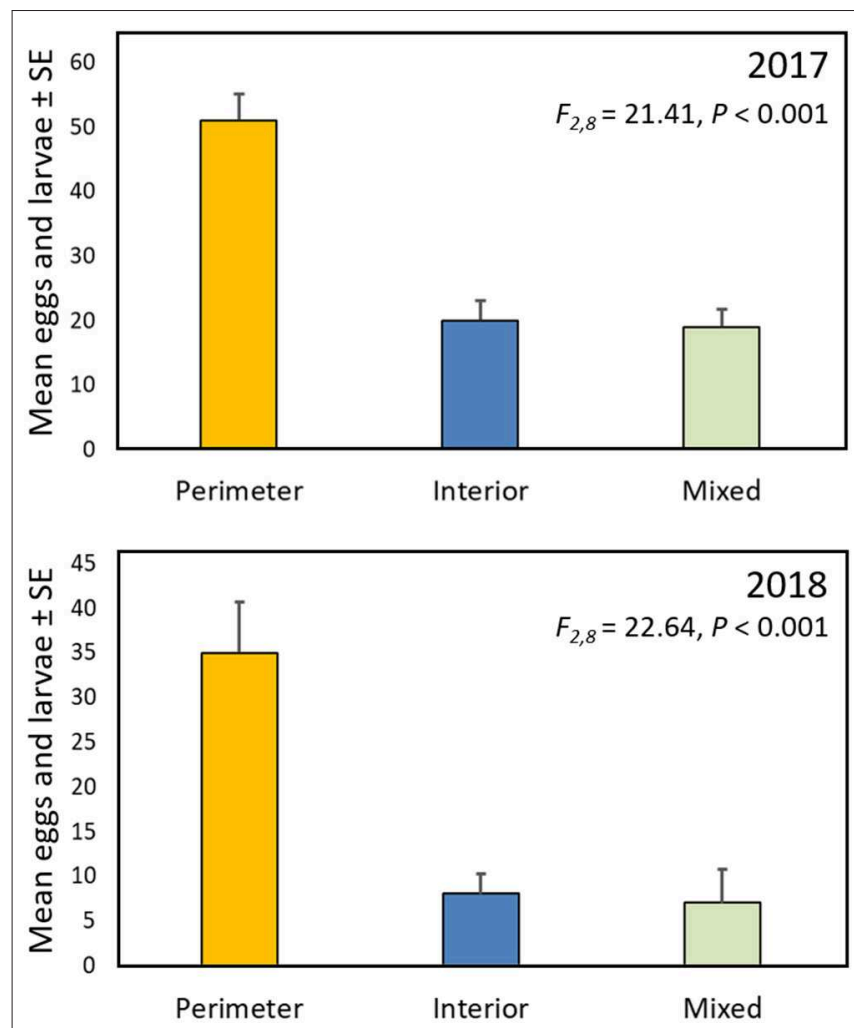

FIGURE 3 | Mean ( \pm SE) total monarch eggs and larvae per garden for the three garden designs described in Figure $\mathbf{1}$.

Stenoien et al., 2015; Baker and Potter, 2018; Geest et al., 2019). The present study indicates that the layout of such gardens strongly influences the extent to which the milkweeds therein are found and used. Results from each of its components; i.e., numbers of eggs and larvae in existing Monarch Waystations, colonization of replicated gardens with different configurations, and oviposition on milkweeds with or without surrounding non-host vegetation, support the hypothesis that at least within small gardens, milkweeds are more susceptible to discovery and oviposition when they are spatially separated from nectar and non-host plants as opposed to being closely intermixed with them.

Host-finding by most butterfly species involves a sequence of behaviors including habitat location, orientation, landing, and plant surface evaluation (Renwick and Chew, 1994). Monarch adults are highly vagile and move extensively between habitat patches with milkweeds and nectar plants, but the relative distances over which they use visual or olfactory cues to locate resources are poorly understood (Zalucki et al., 2016). Caged lab-reared monarchs learned to associate the color and shape of artificial flowers with a nectar reward in the laboratory (Cepero et al., 2015), suggesting they also use such visual cues when orienting to hosts in the field. Upon landing, females engage contact chemoreceptors on their antennae and tarsi to assess plant suitability for oviposition, with flavonol glycosides in asclepiad hosts serving as oviposition stimulants

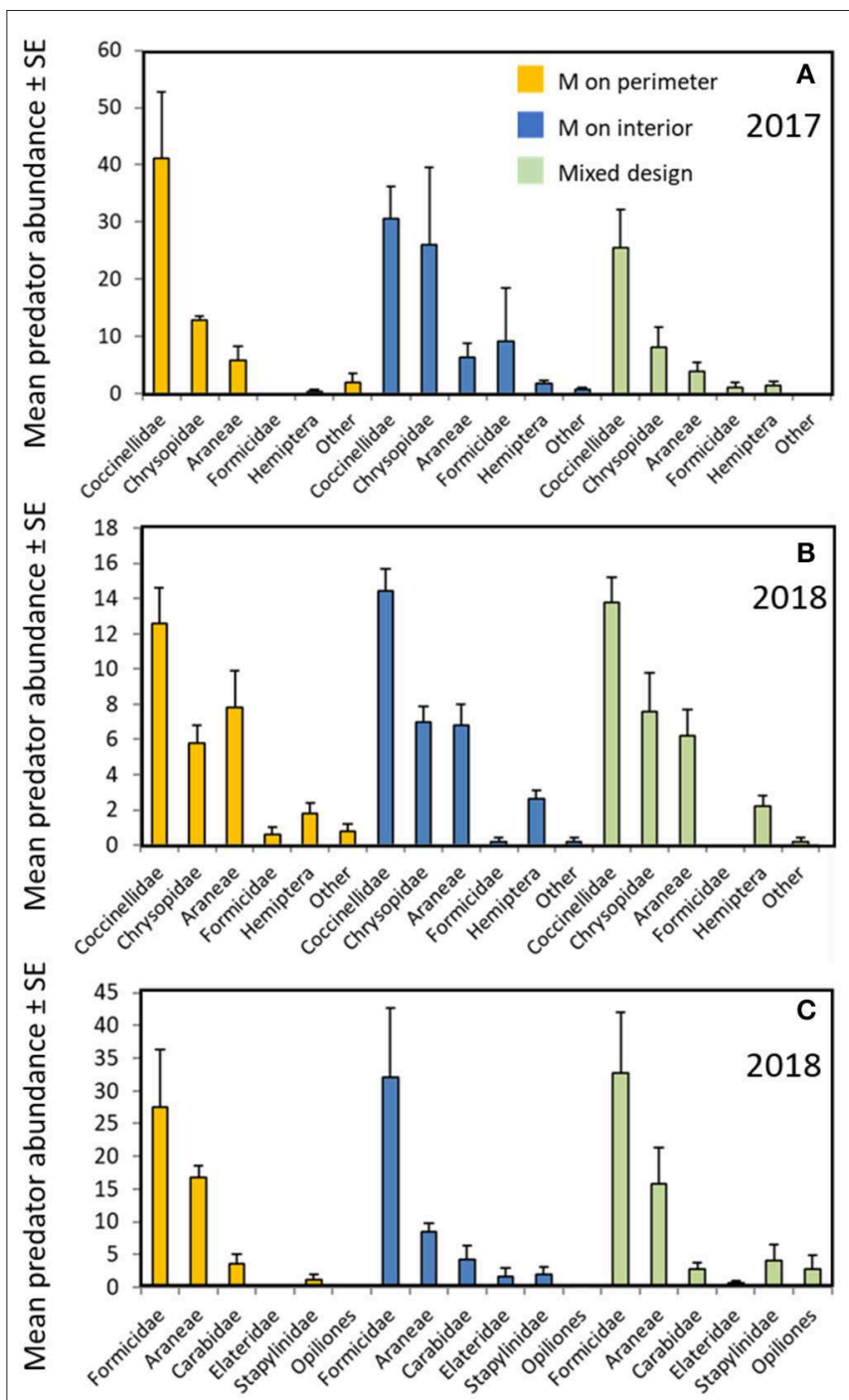

FIGURE 4 | Predator abundance by garden design; Milkweed (MW) on perimeter (orange), Milkweed on interior (blue), Milkweeds intermixed (green). (A) Predator groups observed on host plant foliage in gardens (2017); (B) Predator groups observed on host plant foliage in gardens (2018); (C) Predator groups collected in pitfall traps in the gardens (2018). Counts are means \pm (SE) per garden treatment combined. Garden design did not significantly affect counts of any predator group (ANOVA, all $P \geq 0.24$ ).

(Baur et al., 1998). Monarchs encountering natural stands of milkweed tend to lay more eggs on taller plants than on shorter ones, and more eggs per plant on isolated plants, and on plants at the edge of a patch compared to ones in a patch center (Zalucki and Kitching, 1982a,b; Zalucki et al., 2016).

In our study the gardens were standardized by area and botanical composition. All gardens contained the same number of milkweeds, but the interplant distances between milkweeds differed and were systematically greater in the "perimeter milkweed" layout than in the other garden designs. Because monarchs are known to preferentially oviposit on 


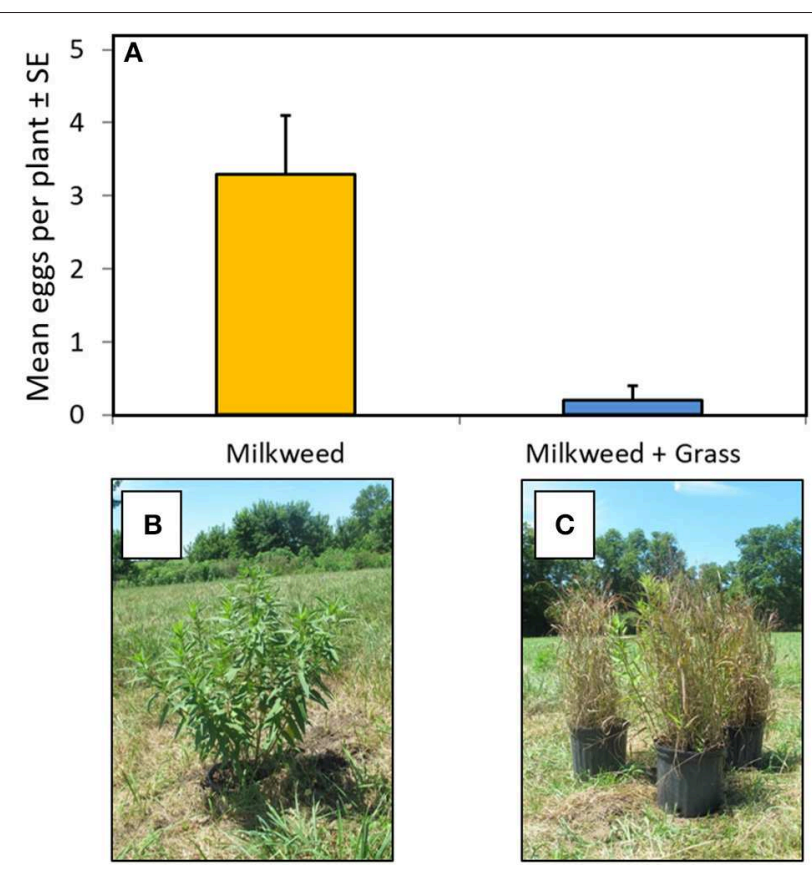

FIGURE 5 | (A) Abundance of monarch eggs observed on isolated milkweed plants and milkweeds visually obstructed by ornamental grasses. (B) Isolated potted milkweed set at ground level. (C) Milkweed visually obstructed by ornamental grasses. Means for isolated vs. obstructed plants differ significantly $\left[F_{(1,5)}=17.87, P<0.01\right]$.

isolated milkweeds, this may have influenced the results. Our purpose, however, was to find ways to optimize monarch use at the whole-garden scale by comparing same-sized gardens planted in different configurations. Consistent with Pitman et al. (2018), who found higher egg densities in small $\left(<16 \mathrm{~m}^{2}\right)$, low-density $\left(0.1-2\right.$ milkweed per $\left.\mathrm{m}^{2}\right)$ milkweed patches in agricultural areas than in larger, higher-density milkweed patches, our small experimental gardens and surveyed Monarch Waystations were readily colonized and used by monarchs.

Visual and chemical stimuli from host and non-host plants can affect specialist herbivores' ability to find and colonize habitat patches, and their behavior in those patches (Tahvanainen and Root, 1972; Root, 1973; Risch, 1981; Finch and Collier, 2000; Bruce et al., 2005). The strength of attractive stimuli for a particular herbivore determines what Root (1973) called "resource concentration" which is affected in turn by density and spatial arrangement of host and non-host plants, and potential interference from non-hosts. (Root, 1973)Resource Concentration Hypothesis predicts that a specialist herbivore approaching a habitat will have greater difficulty locating a host plant when the relative resource concentration is lower. Nonhost vegetation may impair specialists' host-finding by physical obstruction, visual camouflage, making it more difficult for the herbivore to identify correct blends of volatiles produced by host plants against a complex background of volatiles from non-hosts, shading, or otherwise causing host plants to become less attractive or suitable (Tahvanainen and Root, 1972; Root, 1973; Risch, 1981; Bruce et al., 2005). Moreover, "inappropriate" landings on non-hosts may cause specialists to emigrate more quickly from mixed-plant habitat patches of low resource concentration (Root, 1973; Risch, 1981; Finch and Collier, 2000). There is evidence that monarchs are more likely to find and oviposit on milkweeds growing in monoculture agricultural fields than on milkweeds embedded in more botanically diverse habitats such as roadsides, nature preserves, and prairies (Pleasants and Oberhauser, 2013).

Some other diurnal specialist butterflies (e.g., the pipevine swallowtail Battus philenor) that use visual cues, e.g., leaf shape, when approaching host plants for oviposition have more difficulty locating hosts growing amid non-host vegetation than when such vegetation is removed (Rausher, 1981). A similar phenomenon, involving both visual camouflage and physical obstruction, may explain the results from this study. Results of our trial comparing oviposition on individual milkweed plants surrounded or not surrounded by non-host grasses also support the visual camouflage/physical obstruction hypothesis.

Resource concentration and accessibility may also help to explain why female monarchs moving amongst natural patches of milkweed tend to lay more eggs on relatively taller, single, isolated, or edge plants (see above). Indeed, Zalucki and Kitching (1982b) predicted that once a female finds a habitat patch, her movements will be determined by local environmental stimuli; e.g., host plant spacing, flowering plants, and edges, as well as her physiological condition. Those movements determine patch use, and how quickly a patch is "lost" by the butterfly wandering out of it.

An alternative hypothesis for why we found fewer monarch eggs and larvae in gardens having the milkweeds closely intermixed with nectar and non-host plants is that predatory invertebrates might be more abundant in such gardens, or might more readily move from non-host plants to prey on monarchs on adjacent milkweeds. However, our pitfall traps and direct inspections of milkweed plants found no evidence that garden design affected abundance of any predator group. We did not measure parasitism, or losses to birds, vespid wasps, or other flying predators, but there is no reason to expect those mortality agents would be any more or less prevalent in gardens having different layouts of the same plants. Indeed, visually-searching predators would seemingly have less difficulty finding monarch larvae on milkweeds not intermixed with other plants which, if affected by garden configuration, would have contributed to per-garden populations opposite of what we found.

Of those landscape features we analyzed, unimpeded northsouth access to gardens was the strongest predictor of monarch egg and larval abundance in citizen-planted Monarch Waystations. Although monarchs foraging locally may approach and leave milkweed patches from all directions (Zalucki and Kitching, 1982b), unimpeded north/south access to gardens may be particularly important for them to be encountered and used when adults are flying predominantly southward during their fall migration or northward during spring migration. North-south access may also be important because availability of nectar sources, particularly during autumn migration, may 
be critical to monarchs' migration success (Saunders et al., 2019). Interestingly, neither overall percentage of hardscape within a $100 \mathrm{~m}$ radius of the gardens, nor the percentage of total $\left(360^{\circ}\right)$ access blocked by buildings, was a significant determinant of monarch use. Several of the gardens with relatively high numbers of monarchs were located close to the east or west side of buildings, which may account for the positive correlation between those factors in the multivariate analysis. Orientation of a garden in relation to structures, not the proximity per se, may affect monarch use. Nevertheless, the two least productive Waystations we surveyed were the only ones located in courtyards where access to them was blocked by structures. Further research on monarch foraging in relation to hardscape and other features of urban landscapes is warranted.

Despite the public's high level of enthusiasm and capacity for monarch-friendly gardening and projections that the urban sector can make important contributions to monarch recovery (Thogmartin et al., 2017; Johnston et al., 2019), the conservation value of such gardens remains uncertain. That urban milkweed gardens have the potential to recruit monarchs, often with higher egg-loading per plant than occurs in natural milkweed stands, is established (Cutting and Tallamy, 2015; Stenoien et al., 2015; Baker and Potter, 2018; Geest et al., 2019). Such gardens, however, could serve as ecological traps if they expose monarch larvae to increased risk of predation, disease, or pesticides (Majewska et al., 2018; Geest et al., 2019). We did not measure egg or larval survival, but earlier studies found no difference in overall survival (Cutting and Tallamy, 2015), or in mortality from parasitic tachinid flies or the protozoan Ophryocystis electroscirrha (Geest et al., 2019) between urban gardens versus more natural sites in meadows or conservation reserves, respectively. We have documented high rates of European paper wasp, Polistes dominula, predation on monarch larvae in some urban gardens (Baker and Potter, unpublished). Given the propensity of this wasp to nest in building eaves, cavities, and other sheltered places associated with human structures (Liebert et al., 2006), it could potentially pose a greater hazard to monarchs in urban settings than in more natural ones.

Regardless of their value in helping to restore the eastern migratory monarch population, Monarch Waystations and similar gardens provide opportunities to engage large numbers of people in reconciliation ecology. While the magnitude of the current extinction crisis is widely recognized by scientists (IPBES, 2019), we are witnessing an "extinction of experience"

\section{REFERENCES}

Andow, D. A. (1991). Vegetational diversity and arthropod population response. Annu. Rev. Entomol. 36, 561-586. doi: 10.1146/annurev.en.36.010191.003021

Aronson, M. F. J., Lepczyk, C. A., Evans, K. L., Goddard, M. A., Lerman, S. B., MacIvor, J. S., et al. (2017). Biodiversity in the city: key challenges for urban green space management. Front. Ecol. Environ. 15, 189-196. doi: 10.1002/fee.1480

Baker, A. M., and Potter, D. A. (2018). Colonization and usage of eight milkweed (Asclepias) species by monarch butterflies and bees in urban garden settings. J. Insect Conserv. 22, 405-418. doi: 10.1007/s10841-0180069-5
(Pyle, 1993; Miller, 2005; Goddard et al., 2010) whereby the US general public, $80 \%$ of which now lives in metropolitan areas, is increasingly estranged from the natural world. Gardening for monarchs, whether by individual landowners, school children, or organizations, can help foster personal engagement with nature, providing social and educational connections that enrich urban residents' quality of life, and engendering public support for protecting native species (Miller, 2005; Goddard et al., 2010). Our findings suggest guidelines for designing small gardens that can help make the urban sector's contributions to monarch habitat restoration more rewarding for participants, and of greater value to monarch recovery.

\section{DATA AVAILABILITY STATEMENT}

The raw data supporting the conclusions of this manuscript will be made available by the authors, without undue reservation, to any qualified researcher.

\section{AUTHOR CONTRIBUTIONS}

$\mathrm{AB}$ and DP conceived the project and contributed to the study design, analyses, and writing the manuscript. $\mathrm{AB}$ conducted most of the fieldwork with help from undergraduate field assistants.

\section{FUNDING}

Funding was provided by USDA-NIFA-SCRI grant 201651181-235399 administered through IR4 Grant 2015-3438323710, BASF Living Acres Program, US Golf Association, the Horticultural Research Institute, Applewood Seed Co., University of Kentucky Nursery Research Endowment Fund, and USDANIFA Hatch Project no. 2351587000.

\section{ACKNOWLEDGMENTS}

We thank R. Brockman, M. Geis, B. Mach, T. D. McNamara, K. O'Hearn, C. T. Redmond, and L. Wallis for field and lab assistance, G. Munshaw for granting access to the experimental garden site, members of the Lexington Chapter of Wild Ones and others for permission to monitor their Monarch Waystations, R. Bessin for statistical advice, N. Barnes, S. Bhatt, and V. Ligenza for help with Waystation monitoring, and S. Malcolm, J. Lensing, and reviewers for insightful comments and suggestions. Osgathorpe, L. M., et al. (2015). Where is the UK's pollinator biodiversity? The importance of urban areas for flower-visiting insects. Proc. R. Soc. B 282:20142849. doi: 10.1098/rspb.2014.2849

Baur, R., Haribal, M., Renwick, J. A. A., and Städler, E. (1998). Contact chemoreception related to host selection and oviposition behaviour in the monarch butterfly, Danaus plexippus. Physiol. Entomol. 23, 7-19. doi: 10.1046/j.1365-3032.1998.2310007.x

Brower, L. P., Taylor, O. R., Williams, E. H., Slayback, D. A., Zubieta, R. R., and Ramírez, M. I. (2011). Decline of monarch butterflies overwintering in Mexico: is the migratory phenomenon at risk? Insect Conserv. Divers. 5, 95-100. doi: 10.1111/j.1752-4598.2011.00142.x 
Bruce, T. J. A., Wadhams, L. J., and Woodcock, C. M. (2005). Insect host location: a volatile situation. Trends Plant Sci. 10, 269-274. doi: 10.1016/j.tplants.2005.04.003

Cepero, L. C., Rosenwald, L. C., and Weiss, M. R. (2015). The relative importance of flower color and shape for the foraging monarch butterfly (Lepidoptera: Nymphalidae). J. Insect Behav. 28, 499-511. doi: 10.1007/s10905-015-9519-z

Cutting, B. T., and Tallamy, D. W. (2015). An evaluation of butterfly gardens for restoring habitat for the monarch butterfly (Lepidoptera: Danaidae). Environ. Entomol. 44, 1328-1335. doi: 10.1093/ee/nvv111

Finch, S., and Collier, R. H. (2000). Host-plant selection by insects - a theory based on 'appropriate/inappropriate landings' by pest insects of cruciferous plants. Entomol. Exp. Appl. 96, 91-102. doi: 10.1046/j.1570-7458.2000.00684.x

Francis, R. A., and Lorimer, J. (2011). Urban reconciliation ecology: the potential of green roofs and walls. J. Environ. Manage. 92, 1429-1437. doi: 10.1016/j.jenvman.2011.01.012

Geest, E. A., Wolfenbarger, L. L., and McCarty, J. R. (2019). Recruitment, survival, and parasitism of monarch butterflies (Danaus plexippus) in milkweed gardens and conservation areas. J. Insect Conserv. 23, 211-224. doi: 10.1007/s10841-018-0102-8

Goddard, M. A., Dougill, A. J., and Benton, T. G. (2010). Scaling up from gardens: biodiversity conservation in urban environments. Trends Ecol. Evol. 25, 90-98. doi: 10.1016/j.tree.2009.07.016

Gustafsson, K. M., Agrawal, A. A., Lewenstein, B. V., and Wolf, S. A. (2015). The monarch butterfly through time and space: the social construction of an icon. BioScience 65, 612-622. doi: 10.1093/biosci/biv045

Hall, D. M. (2016). The city as a refuge for insect pollinators. Conserv. Biol. 31, 24-29. doi: $10.1111 /$ cobi.12840

IPBES (2019). Global Assessment Report on Biodiversity and Ecosystem Services of the Intergovernmental Science- Policy Platform on Biodiversity and Ecosystem Services. eds. E. S. Brondizio, J. Settele, S. Díaz, and H. T. Ngo. IPBES Secretariat, Bonn.

Johnston, M. K., Hasle, E. M., Klinger, K. R., Lambruschi, M. P., Derby Lewis, A., Stotz, D. F., et al. (2019). Estimating milkweed abundance in metropolitan areas under existing and user-defined scenarios. Front. Ecol. Evol.7:210. doi: $10.3389 /$ fevo.2019.00210

Kasten, K., Stenoien, C., Caldwell, W., and Oberhauser, K. S. (2016). Can roadside habitat lead monarchs on a recovery route? J. Insect. Conserv. 20, 1047-1057. doi: 10.1007/s10841-016-9938-y

Lepczyk, C. A., Aronson, M. F. J., Evans, K. L., Goddard, M. A., Lerman, S. B., and MacIvor, J. S. (2017). Biodiversity in the city: fundamental questions for understanding the ecology of urban green spaces for biodiversity conservation. BioScience 67, 799-807. doi: 10.1093/biosci/bix079

Liebert, A. E., Gamboa, G. J., Stamp, N. E., Curtis, T. R., Monnet, K. M., Turillazzi, S., et al. (2006). Genetics, behavior and ecology of a paper wasp invasion: Polistes dominulus in North America. Ann. Zool. Fenneci 43, 595-624. Available online at: http://www.sekj.org/PDF/anzf43/anzf43-595.pdf

Majewska, A. A., Sims, S., Wenger, S. J., Davis, A. K., and Altizer, S. (2018). Do characteristics of pollinator-friendly gardens predict the diversity, abundance, and reproduction of butterflies? Insect Conserv. Divers. 11, 370-382. doi: 10.1111/icad.12286

Malcolm, S. B. (2018). Anthropogenic impacts on mortality and population viability of the monarch butterfly. Annu. Rev. Entomol. 63, 277-302. doi: 10.1146/annurev-ento-020117-043241

Miller, J. R. (2005). Biodiversity conservation and the extinction of experience. Trends Ecol. Evol. 20, 430-434. doi: 10.1016/j.tree.2005.05.013

Oberhauser, K. S., Wiederholt, R., Diffendorfer, J. E., Semmens, D., Ries, L., Thogmartin, W. E., et al. (2017). A trans-national monarch butterfly population model and implications for regional conservation priorities. Ecol. Entomol. 42, 51-60. doi: 10.1111/een.12351

Pitman, G. M., Flockhart, D. T., and Norris, D. R. (2018). Patterns and causes of oviposition in monarch butterflies: implications for milkweed restoration. Biol. Conserv. 217, 54-65. doi: 10.1016/j.biocon.2017.10.019

Pleasants, J. (2017). Milkweed restoration in the Midwest for monarch butterfly recovery: estimates of milkweeds lost, milkweeds remaining and milkweeds that must be added to increase the monarch population. Insect Conserv. Divers. 10, 42-53. doi: 10.1111/icad.12198

Pleasants, J. M., and Oberhauser, K. S. (2013). Milkweed loss in agricultural fields because of herbicide use: effect on the monarch butterfly population. Insect Conserv. Divers. 6, 135-144. doi: 10.1111/j.1752-4598.2012.00196.x

Pyle, R. (1993). The Thunder Tree: Lessons From an Urban Wildland. Corvallis, OR: Oregon State University Press, 130-143.

Rausher, M. D. (1981). The effect of native vegetation the susceptibility of Artistolochia reticulata (Aristolochiaceae) to herbivore attack. Ecology 62, 1187-1195. doi: 10.2307/1937283

Renwick, J. A. A., and Chew, F. S. (1994). Oviposition behavior in Lepidoptera. Annu. Rev. Entomol. 39, 377-400. doi: 10.1146/annurev.en.39.010194.002113

Reppert, S. M., and de Roode, J. C. (2018). Demystifying monarch butterfly migration. Curr. Biol. 28, R1009-R1022. doi: 10.1016/j.cub.2018.02.067

Risch, S. J. (1981). Insect herbivore abundance in tropical monocultures and polycultures: an experimental test of two hypotheses. Ecology 62, 1325-1340. doi: $10.2307 / 1937296$

Root, R. B. (1973). Organization of a plant-arthropod association in simple and diverse habitats: the fauna of collards (Brassica Oleracea). Ecol. Monogr. 43, 95-124. doi: 10.2307/1942161

Rosenzweig, M. L. (2003a). Win-Win Ecology: How the Earth Species can Survive in the Midst of Human Enterprise. New York, NY: Oxford University Press.

Rosenzweig, M. L. (2003b). Reconciliation ecology and the future of species diversity. Oryx 37, 194-205. doi: 10.1017/S0030605303000371

Saunders, S. P., Ries, L., Neupane, N., Ramírez, M. I., Garcia-Serrano, E., Rendón-Salinas, E., et al. (2019). Multiscale factors drive the size of winter monarch colonies. Proc. Nat. Acad. Sci. U.S.A. 116, 8609-8614. doi: $10.1073 /$ pnas. 1805114116

Schultz, C. B., Brown, L. M., Pelton, E., and Crone, E. E. (2017). Citizen science monitoring demonstrates dramatic declines of monarch butterflies in western North America. Biol. Conserv. 214, 343-346. doi: 10.1016/j.biocon.2017.08.019

Stenoien, C., Nail, K. R., and Oberhauser, K. S. (2015). Habitat productivity and temporal patterns of monarch butterfly egg densities in the eastern United States. Ann. Entomol. Soc. Am. 108, 670-679. doi: 10.1093/aesa/sav054

Tahvanainen, J. O., and Root, R. B. (1972). The influence of vegetational diversity on the population ecology of a specialized herbivore, Phyllotreta cruciferae (Coleoptera: Chrysomelidae). Oecologia 10, 321-346. doi: 10.1007/BF00345736

Thogmartin, W. E., López-Hoffman, L., Rohweder, J., Diffendorfer, J., Drum, R., Semmens, D., et al. (2017). Restoring monarch butterfly habitat in the Midwestern US: 'all hands on deck'. Environ. Res. Lett. 12:074005. doi: 10.1088/1748-9326/aa7637

Vidal, O., and Rendón-Salinas, E. (2014). Dynamics and trends of overwintering colonies of the monarch butterfly in Mexico. Biol. Conserv. 180, 165-175. doi: 10.1016/j.biocon.2014.09.041

Zalucki, M. P., and Kitching, R. L. (1982a). Dynamics of oviposition in Danaus plexippus (Insecta: Lepidoptera) on milkweed, Asclepias spp. J. Zool. 198, 103-116. doi: 10.1111/j.1469-7998.1982.tb02063.x

Zalucki, M. P., and Kitching, R. L. (1982b). The analysis and description of movement in adult Danaus plexippus L. (Lepidoptera: Danainae). Behaviour 80, 174-198. doi: 10.1163/156853982X00346

Zalucki, M. P., Parry, H. R., and Zalucki, J. M. (2016). Movement and egg laying in monarchs: to move or not to move, that is the equation. Austral. Ecol. 41, 154-167. doi: 10.1111/aec.12285

Conflict of Interest: The authors declare that the research was conducted in the absence of any commercial or financial relationships that could be construed as a potential conflict of interest.

Copyright (c) 2019 Baker and Potter. This is an open-access article distributed under the terms of the Creative Commons Attribution License (CC BY). The use, distribution or reproduction in other forums is permitted, provided the original author(s) and the copyright owner(s) are credited and that the original publication in this journal is cited, in accordance with accepted academic practice. No use, distribution or reproduction is permitted which does not comply with these terms. 